\title{
留置カテーテル監視装置の研究
}

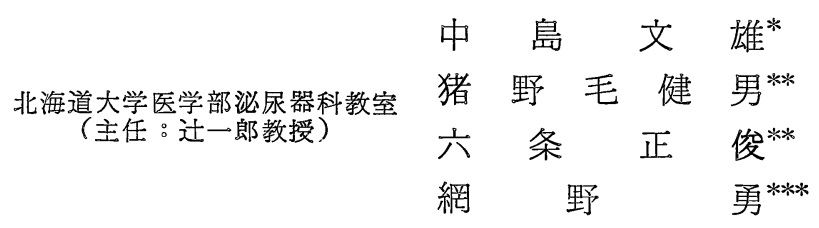

\section{A STUDY ON MONITORING DEVICES OF URINEDROPS THROUGH INDWELLING CHATHETER.}

\author{
Fumio Nakajima, Takeo Inoke, Masatoshi Rokujo and Isamu Amino \\ From the Department of Urology Hokkaido University School of Medicine.
}

(Director: Prof. I. Tsuji.) or not.

It is very important after urinary tract operations whether the state of indwelling catheter is adequate

Three types of monitoring device are presented here to watch urine flow through indwelling catheter in nurse station.

1) Signal lump for urine drops:

A neon lump is on and off corresponding to each urine drop.

2) Recorder for urine drops:

The recording ammeter indicates the present and past state of urine flow.

3) Alarm apparatus for interruption of urine flow:

The buzzer of the apparatus alarms when urine drops stopped for a certain minute previously setted.

各種の尿路の手術で, 術後留置カテーテルを置いた場 合。このカテーテルが適正によく働いて常に円滑な尿流 を保つことが極めて大切であり，この為に頻回な見迴り を必要とする訳であるが，実際問題としてこの事は多数 の患者を収容している場合には，特に深夜に於ては，医 師。看護婦にとりかなりの角担となつている。この点も しカテーテルの尿流状態を電気的に記録する装置, 更に 尿流が一定時間以上途切れたら，看護婦詰所に自動的に 警報する装置があれば非常に便利である事は云うまでも ない. 文献上この様な装置についての研究発表は従来殆 んどないと言つてよい現状である。るちろん現在の進歩 したエレクトロニクスを用いればこのような装置は容易 に開発出来る筈であるが。実際には commercial base にのらないせいか, 具体的な要求がない為か作られてい ない。私達は数年前より比較的小型かつ安価な尿流監視 装置を作る事を考觉てはいたが，他方面の研究に追われ

* 講師, ***助手, ****大学院学生
てなかなか進ちよくせず，ようやく最近になつて一応役 に立つ装置を製作出来た。もちろんまで欠点も多く改良 を要する点も多いが一応ここに報告したい．

試作 1 号：尿滴信号燈。むず初めに我々は図 1 の如き 極めて簡単な装置を作製した。これは留置カテーテルに つないだ tube の先端に図 2 の如きステンレススチール 製の電極をつけ, tube より一滴の尿が落下する度に回 路が閉じ nurse-station にあるネオンランプがその都度 点滅する，ネオンランプが点登しつぱなし，又は消えつ ぱなしの時は尿が流れていない訳で, 患者の bed 迄行

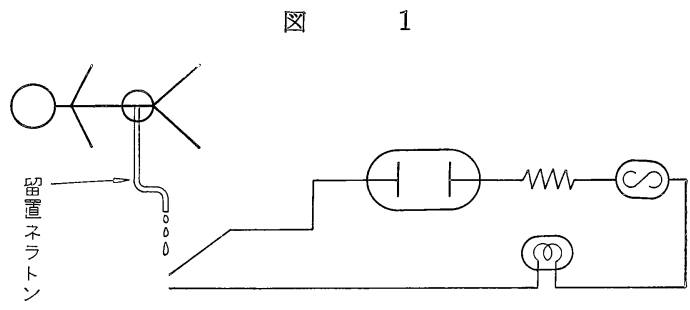




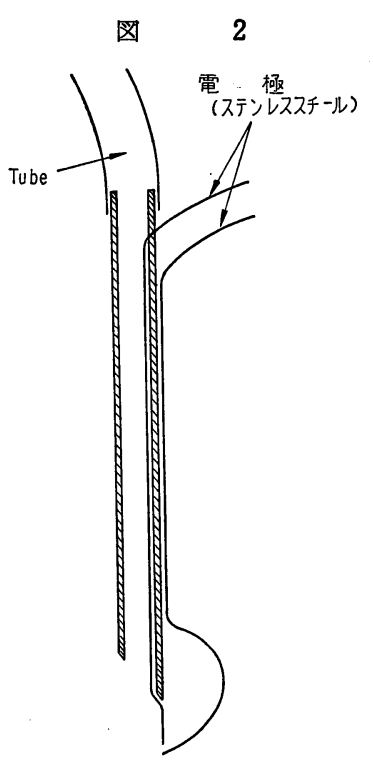

かずに nurse-station にいながら尿が流れている様子が わかる。

試作 II 号：尿滴記録装置

次に我々が考案した装置は図 3 亿示す如く尿が導尿管
図 $\quad 3$

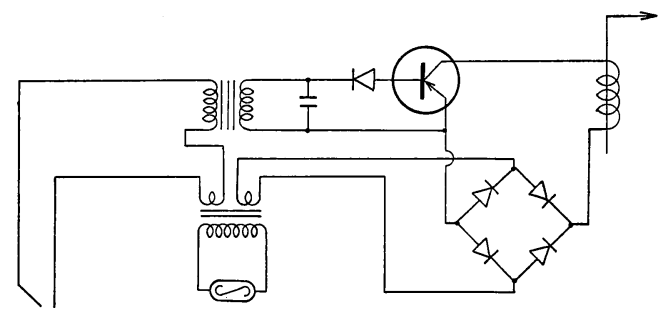

図 4

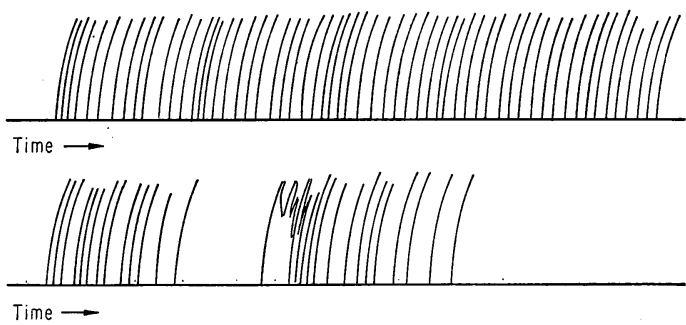

先端の図 2 の電極にふれ，回路が閉じ低電圧の交流が流 れ, この電流が変圧器を介し, 更にダイオードによつて 検波され，トランジスターで増巾され，記録電流計によ つて記録されるものでめる。これによると一滴の尿に対

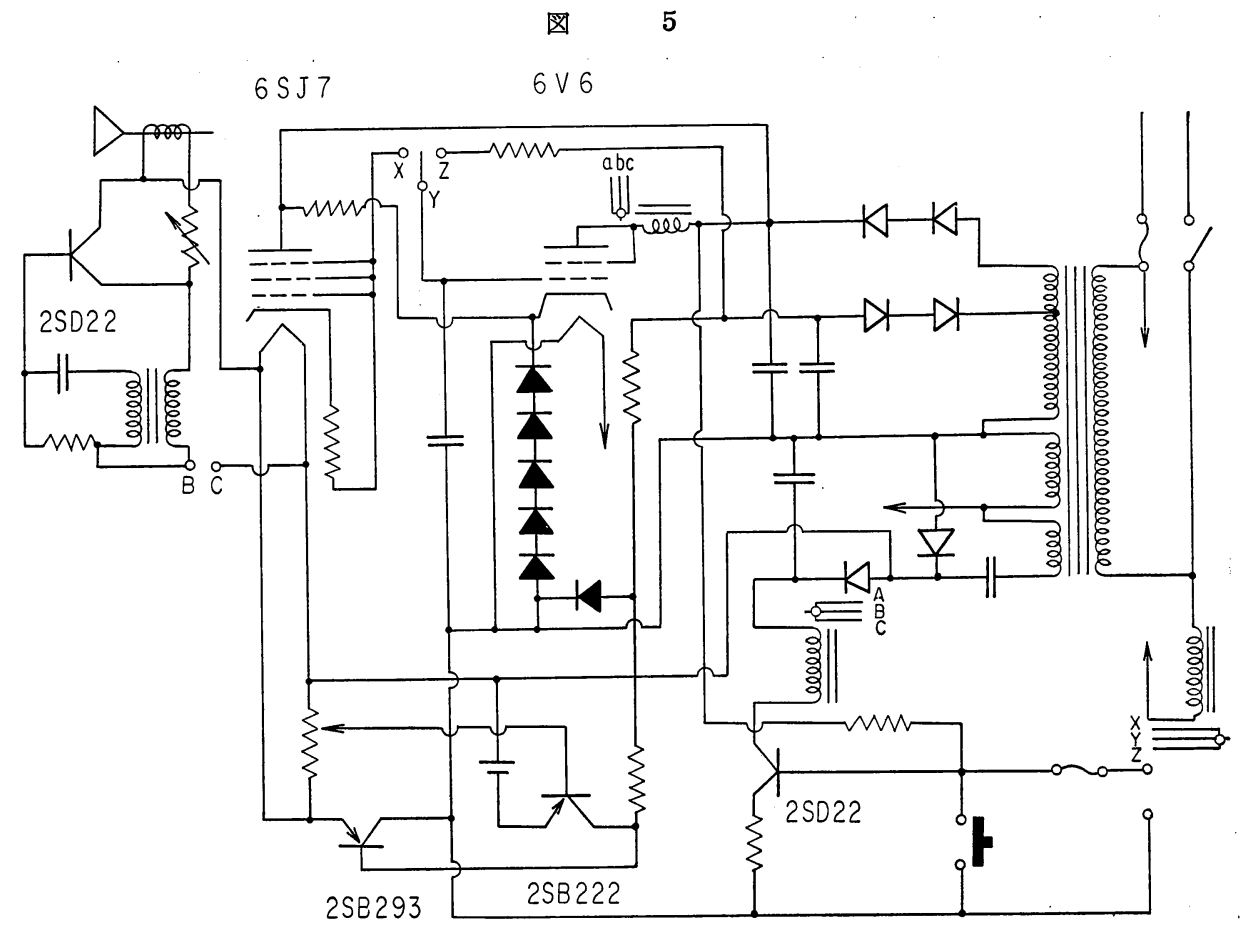


図

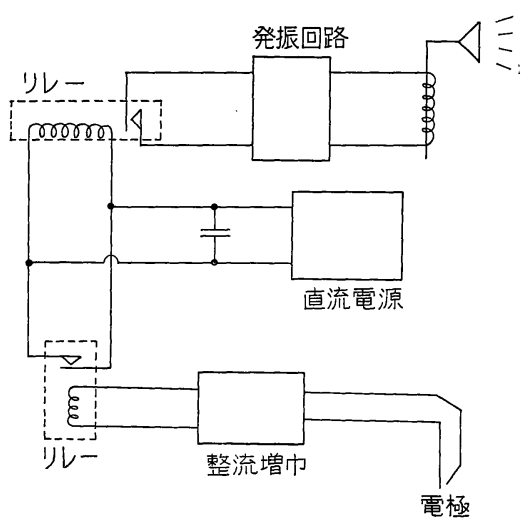

応して回路が閉じ記録電流計の針が一回動くわけで図 4 の如きグラフが得られるわけである．これによつて現在 の状態を知るのみでなく過去の尿流状態をも知る事が出 来る.電極を流れる電流を交流にしたのは，電極に於け る電気分解, 分極を避ける為である. 以上の試作 I, I の装置ではいずれも尿流が止つた事を早く知る為には， 常にネオンランプや記録用紙の曲線に注意していなけれ ばならない訳である。理想的には，注意していなくても 一定時間尿流がとぎれれば alarm を発する装置が 望ま しい訳である。

試作黑号：尿滴途絶警報装置

一定時間信号がなければ alarm を発する装置は一見 容易な様であるが簡単な電子装置で安価でしかも耐久性 のあるものとなると種々の面でかなりの困難があり，今 回我々が試作したものは, 最も常識的なコンデンサーの 充電時間を応用した装置である. 回路は図 5 に示した が，これを模式化すると図6の如くになる。容量の大き
いコンデンサーは交流を整流して作つた直流電源につな がつている. 時間の経過と共にコンデンサーの蓄電電圧 は上つて行くが，I，II司じ tube の先端に set した 電極間に尿が流れると尿堂通じ少電流が流れ，これがり レーを作動してコンデンサー両極板間に並列に入つたス イッチを瞬間的に閉じ，コンデンサーは短絡されて，電 圧は0にもどるわけである。この電流による短絡が一定 時間起らないとコンデンサー内の電圧が所定の電圧に達 し,リレーが働いてて発振回路の電源が入る事により, ス ピーカーから発振音が出て，一定時間尿流がなかつた事 を知らせるわけである。我々はコンデンサーの容量を $100 \mu \mathrm{F}$ とし, 約 5 分間尿滴下が止まれば, 警報が鳴る様 にした．装置の原価は一組約 3 万円程度であつた．勿論 更に多数作れば安価になる筈である。この装置を臨床的 飞使用したのは恥骨上前立腺剔出術 3 , T.U.R.P. 2, T.U.R. Bt。2，腎瘦 1 ，尿管皮膚移植 1 ，計 9 例であ るが，いずれも萎ぼ満足すべき結果が得られた。この装 置の欠点は凝血等が電極間につまつた時は回路が入りつ ぱなしで alarm が鳴らない訳で、これを解決するには この逆働く装置を作ればよい訳であるが，コストがほ ぽ 2 倍になる. 又耐久性とか両電極間に於ける電解, 分 極等色々の問題があり,な叔今後研究を要する点も多い が，ここに記して，大方の御批判を乞う次第である.

\section{結語}

我々の試作した留置カテーテルの尿流監視装置 3 種を 紹介した。

\section{交献}

1) 立花太郎, 古賀正三 : 実験窒に於ける電気技術 ヘンドブック, 東京化学同人。

（昭和41年11月 13 日受付） 